\title{
Hemothorax caused by rupture of a primitive thoracic leiomyosarcoma of the thoracic aorta: Description of a case and literature review
}

\author{
F. Catena, R. Bianchi, L. Ansaloni, and A. D. Pinna, Bologna, Italy
}

$\mathrm{T}$ The first diagnosis of leiomyosarcoma of a large blood vessel (inferior vena cava) was made by Wirchow, as reported by Varela-Duran, Oliva, Rosai, ${ }^{1}$ and it was later described by Perl $^{2}$ in 1871 . In 1873 Brodowsky $^{3}$ reported the first case of aortic leiomyosarcoma. Since then, 32 cases of aortic leiomyosarcoma have been reported in the literature but only 4 cases of thoracic leiomyosarcoma ${ }^{4-9}$ treated in an emergency setting (Table 1).

The emergency diagnosis of aortic leiomyosarcoma can be problematic. Because of the initial presentation, the first strategy is always to treat a more common problem (ruptured thoracic aorta). It is then necessary to change the approach while the operation is being carried out according to oncologic surgery principles. Leiomyosarcomas are clinically silent until the moment of rupture, and the emergency operation has a high perioperative mortality related to hemorrhagic shock. ${ }^{7}$ Owing to its biologic properties, leiomyosarcoma frequently relapses and gives rise to metastasis with a high mortality rate within the first 2 years after diagnosis.,

In the present study we report a case of a patient with leiomyosarcoma of the descending thoracic aorta with contained rupture who required an emergency operation. We discuss diagnostic and therapeutic problems with a review of the literature.

\section{Clinical Summary}

A 53-year-old woman (a family physician) was referred to the emergency department for sudden thoracic pain and syncope with no history of trauma. Medical history was nondiagnostic and she did not report any recent symptoms. The electrocardiogram showed no abnormalities, and the chest $\mathrm{x}$ - ray film revealed a right pleural effusion. A blood test showed moderate anemia (hemoglobin $8.7 \mathrm{mg} / \mathrm{dL}$ ) and vital parameters were within normal limits.

The patient was submitted to abdominal and thoracic computed tomographic scanning, which showed a rupture of the descending thoracic aortic wall of unknown origin with mediastinal hematoma. The patient then underwent emergency left thoracophrenolaparot-

\footnotetext{
From the Department of General, Emergency and Transplant Surgery, St Orsola-Malpighi University Hospital, Bologna, Italy.

Received for publication Oct 2, 2007; accepted for publication Oct 16, 2007.

Address for reprints: Fausto Catena, MD, 40138 Bologna, Italy (E-mail: fcatena@aosp.bo.it).

J Thorac Cardiovasc Surg 2008;135:688-9

$0022-5223 / \$ 34.00$

Copyright $\odot 2008$ by The American Association for Thoracic Surgery doi:10.1016/j.jtcvs.2007.10.053
}

omy. The intraoperative examination confirmed a left hemothorax caused by a contained rupture of the thoracic aorta. A white-yellow lesion (dimensions $1 \times 2 \mathrm{~cm}$ ) that infiltrated significantly and prevalently into the wall of the aorta and the base of the right lung was found.

After clamping of the ascending and abdominal aorta, a 7-cm segment of thoracic aorta was resected together with a wedge lung resection. The thoracoabdominal aorta was reconstructed with a 16-mm Dacron prosthesis with end-to-end anastomosis between the ascending aorta and the abdominal aorta at the level of the celiac trunk. The postoperative course was uneventful. After 21 days the patient was discharged.

The pathologic report revealed a malignant undifferentiated proliferation from a primitive leiomyosarcoma of the aortic wall with a lung infiltration. Resection margins were normal. The immunohistochemistry examination was positive for vimentin and actin. After evaluation by an oncologist, the patient was not subjected to any adjuvant chemoradiotherapy. She is alive without recurrence at 21 months' follow-up.

\section{Discussion}

Leiomyosarcoma of the large blood vessel is an extremely uncommon disease with a greater incidence between the fourth and the sixth decades of life and with a higher prevalence in men. ${ }^{1,4}$ It originates from the smooth muscular tissue of the aortic wall, and it compresses and infiltrates into the surrounding structures. ${ }^{4}$ When the veins are affected, leiomyosarcoma grows on the inside of the vessel, and it is the cause of deep vein thrombosis (also as first presentation). ${ }^{10}$

Cases of leiomyosarcoma are described in the literature starting from the inferior vena cava and invading the right auricle. ${ }^{11}$ Thirtytwo cases of aortic leiomyosarcoma have been reported in the literature but only 4 of the patients were treated in an emergency setting. ${ }^{4-9}$ Symptoms are aspecific (back, thoracic, or epigastric pain): in some unlucky cases the first presentation is an acute uncontrollable pain caused by aortic rupture and hemorrhagic shock (only 1 such case reported). ${ }^{7}$

Diagnosis is based on angiographic computed tomographic or magnetic resonance scan, but in all 4 patients treated in an emergency setting, a correct preoperative diagnosis was not obtained. In our case computed tomography failed to detect leiomyosarcoma, probably because of its small size.

The only therapy for leiomyosarcoma is surgical resection; the use of chemotherapy (doxorubicin [Adriamycin]) with or without radiotherapy does not change the prognosis. ${ }^{12}$ Recently, tyrosine kinase inhibitors (AG979) were proposed with a significant reduction of the tumoral mass. ${ }^{12}$

At gross examination. leiomyosarcoma appears as a whiteyellow lesion, and the morphologic aspect is of malignant myxoid stromal cells mixed with epithelial cells. Immunohistochemistry shows positivity for vimentin, actin, and desmin. ${ }^{3,6}$ 
TABLE 1. Emergency treated thoracic aorta leiomyosarcoma: literature review

\begin{tabular}{|c|c|c|c|c|c|c|c|c|}
\hline $\begin{array}{l}\text { First author, } \\
\text { year }\end{array}$ & Sex & $\begin{array}{l}\text { Age } \\
\text { (y) }\end{array}$ & Symptoms & Tests & First diagnosis & Metastases & Treatment & Follow-up \\
\hline $\begin{array}{c}\text { Yasuda, } \\
1999\end{array}$ & $\mathrm{~F}$ & 43 & $\begin{array}{l}\text { Acute thoracic pain, } \\
\text { tachycardia }\end{array}$ & $\begin{array}{l}\text { Chest radiograph, } \\
\text { CT }\end{array}$ & $\begin{array}{l}\text { Illa dissecting } \\
\text { aortic } \\
\text { aneurysm }\end{array}$ & Pleura & Surgery & Death after $3 \mathrm{mo}$ \\
\hline $\begin{array}{r}\text { Glock, }^{6} \\
1997\end{array}$ & $\mathrm{M}$ & 58 & Acute thoracic pain & $\begin{array}{l}\text { Chest radiograph, } \\
\text { CT, MRI }\end{array}$ & $\begin{array}{l}\text { Dissecting aortic } \\
\text { aneurysm }\end{array}$ & $\begin{array}{l}\text { Bone, adrenal } \\
\text { glands }\end{array}$ & $\begin{array}{l}\text { Surgery, } \\
\text { radiotherapy, } \\
\text { chemotherapy }\end{array}$ & Death after $16 \mathrm{mo}$ \\
\hline $\begin{array}{l}\text { Testini, }^{7} \\
1996\end{array}$ & M & 69 & Hemorrhagic shock & CT & $\begin{array}{l}\text { Ruptured aortic } \\
\text { aneurysm }\end{array}$ & Liver, lung & Surgery & Death after 50 mo \\
\hline $\begin{array}{l}\text { Steinberg, } \\
1993\end{array}$ & $\mathrm{M}$ & 48 & Abdominal pain & $\begin{array}{l}\text { Chest radiograph, } \\
\text { CT }\end{array}$ & $\begin{array}{l}\text { Ruptured aortic } \\
\text { aneurysm }\end{array}$ & Lung & $\begin{array}{l}\text { Surgery, } \\
\text { chemotherapy }\end{array}$ & Death after $12 \mathrm{mo}$ \\
\hline
\end{tabular}

CT, Computed tomography; MRI, magnetic resonance imaging.

Leiomyosarcoma frequently can lead to widespread metastases to the liver and lung, and these are correlated mainly with the cancer's dimensions (up to $2 \mathrm{~cm}$ ) and with mytotic index (up to 30 for high power fields). Other less frequent metastatic sites are brain, bones, pleura, pancreas, and kidney. Prognosis is poor: in $90 \%$ of cases leiomyosarcoma is lethal within the first 2 years of diagnosis. All reported patients who had emergency treatment had metastasis at the time of the operation (Table 1).

There is a therapeutic problem with leiomyosarcoma: if missed at the preoperative diagnosis, it is important to recognize the tumor during the operation. In case of misdiagnosis, these patients can be treated as subjects with ruptured aorta, leaving in situ the aortic wall with the sarcoma. In the literature review, leiomyosarcoma was diagnosed as an incidental finding at pathologic examination in 2 of 4 cases. $^{4-7}$

It is fundamental to perform an aortic resection with nondiseased margins (if possible, with an intraoperative pathologic examination). In case of localized organ infiltration or adhesion, a wedge resection (if possible) should be carried out in continuity with the aortic wall.

In conclusion, aortic leiomyosarcoma is a rare tumor with rare emergency presentation but with important diagnostic and therapeutic problems. Surgery is the only effective therapy, and it is mandatory to recognize and treat the tumor correctly at the first operation.

\section{References}

1. Varela-Duran J, Oliva H, Rosai J. Vascular leiomyosarcoma. Cancer. 1979;44:1684-91.
2. Perl L. Ein Fall der Sarkomer der Vena cava inferior. Virchows Arch Pathol Anat. 1871;53:378.

3. Brodowski W. Primaeres Sarcomder aortathoracica mit verbreitung des neugehildes in der nuteren koerperhaulfte. Jahresh Leistung Geschl Med. 1873;8:243-5.

4. Yasuda T, Yamamoto S, Yamaguchi S, Ishida Y. Leiomyosarcoma of the thoracic aorta. Jpn J Thorac Cardiovasc Surg. 1999;47:510-3.

5. Navarra G, Occhionorelli S, Mascoli F, Santini M, Benea G, Marzola A. Primary leiomyosarcoma of the aorta: report of a case and review of the literature. J Cardiovasc Surg (Torino). 1994;35:333-6.

6. Glock Y, Laghzaoui A, Wang J, Delisle MB, Bachaud JM, Massabuau P, et al. Fissured leiomyosarcoma of the descending thoracic aorta. Apropos of case and review the literature. Arch Mal Coeur Vaiss. 1997;90:1317-20

7. Testini M, Todisco C, Simone M, Paradiso V, D'Agostino D, Ferlan G, et al. Treatment of haemorrhage following rupture of aortic leiomyosarcoma. J Cardiovasc Surg (Torino). 1996;37:593-6.

8. Steinberg JB, Johnson ER, Benda JA, Lanza LA. Primary leiomyosarcoma of the thoracic aorta presenting as a contained rupture. Ann Thorac Surg. 1993;56:1387-9.

9. Berlin O, Stener B, Kindblom LG, Angervall L. Leiomyosarcomes of venous origin in the extremities. Cancer. 1984;54:2147-59.

10. Dew J, Hansen K, Hammon J, McCoy T, Levine EA, Shen P. Leiomyosarcoma of the inferior vena cava: surgical management and clinical results. Am Surg. 2005;71:497-501.

11. Chice L, Mongredien B, Brocheriou I, Kieffer E. Primary tumors of the thoracoabdominal aorta: surgical treatment of 5 patients and review of the literature. Ann Vasc Surg. 2003;17:354-64.

12. Rende M, Pistilli A, Stabile AM, Terenzi A, Cattaneo A, Ugolini G, et al. Role of nerve growth factor and its receptors in non nervous cancer growth: efficacy of tyrosine kinase inhibitor (AG979) and neutralizing antibodies antityrosine kinase receptor $\mathrm{A}$ and antinerve growth factor: an in vitro and in vivo study. Anticancer Drugs. 2006; 17:929-41. 